\title{
Review Article \\ Cytomegalovirus in the Neonate: Immune Correlates of Infection and Protection
}

\author{
Mark R. Schleiss \\ Department of Pediatrics, University of Minnesota Medical School, \\ Center for Infectious Diseases and Microbiology Translational Research, 2001 6th Street SE, Minneapolis, MN 55455, USA
}

Correspondence should be addressed to Mark R. Schleiss; schleiss@umn.edu

Received 4 February 2013; Accepted 7 March 2013

Academic Editor: Philipp Henneke

Copyright (C) 2013 Mark R. Schleiss. This is an open access article distributed under the Creative Commons Attribution License, which permits unrestricted use, distribution, and reproduction in any medium, provided the original work is properly cited.

\begin{abstract}
Fetal and neonatal infections caused by human cytomegalovirus (CMV) are important causes of morbidity and occasional mortality. Development of a vaccine against congenital CMV infection is a major public health priority. Vaccine design is currently focused on strategies that aim to elicit neutralizing antibody and T-cell responses, toward the goal of preventing primary or recurrent infection in women of child-bearing age. However, there has been relatively little attention given to understanding the mechanisms of immune protection against acquisition of CMV infection in the fetus and newborn and how this information might be exploited for vaccine design. There has similarly been an insufficient study of what deficits in the immune response to CMV, both for mother and fetus, may increase susceptibility to congenital infection and disease. Protection of the fetus against vertical transmission can likely be achieved by protection of the placenta, which has its own unique immunological milieu, further complicating the analysis of the correlates of protective immunity. In this review, the current state of knowledge about immune effectors of protection against CMV in the maternal, placental, and fetal compartments is reviewed. A better understanding of immune responses that prevent and/or predispose to infection will help in the development of novel vaccine strategies.
\end{abstract}

\section{Introduction}

Human cytomegalovirus (CMV) is the most common cause of congenital viral infection in the developed world, occurring in $0.5-2 \%$ of pregnancies in the United States and Europe $[1,2]$. Congenital infections can cause severe sequelae among neonates including sensorineural hearing loss, cerebral palsy, microcephaly, cognitive impairments, and mental retardation [3-5]. During maternal primary infection, and to a lesser extent during recurrent infection, CMV can translocate the placental barrier and can cause infection of the developing fetus $[6,7]$. Infection acquired in utero may have no clinical manifestations, or may manifest with hepatosplenomegaly, thrombocytopenia, cholestatic hepatitis, petechiae and purpura, central nervous system pathologies (including retinitis), viremia, and pneumonia [8]. In addition to being at risk for severe, occasionally life-threatening end-organ disease [9], infants with symptoms at birth also have an increased risk for long-term neurodevelopmental sequelae, including sensorineural hearing loss (SNHL). The long-term neurodevelopmental prognosis of a congenitally infected infant depends upon a number of factors, including the maternal immune status prior to the onset of pregnancy, whether or not she is reinfected with a new strain of CMV during pregnancy, and the timing of acquisition of fetal infection [10-12].

In addition to the impact of CMV infections acquired in utero, postnatal acquisition of CMV can also cause significant morbidity and occasional mortality. Disease is typically not observed in term infants, but can be a substantial problem for low birth weight premature infants [13, 14]. Because of the virtual elimination of transfusion-associated CMV heralded by the advent of leukofiltration of blood products [15], essentially all CMV infections in premature infants are acquired from maternal breast milk [16-18]. As is the case for congenital CMV infections, many breast milk-acquired infections in premature infants are asymptomatic, but a substantial percentage can produce severe, occasionally lifethreatening disease, which can manifest as viremia, neutropenia, thrombocytopenia, hepatitis, pneumonia, enteritis, 


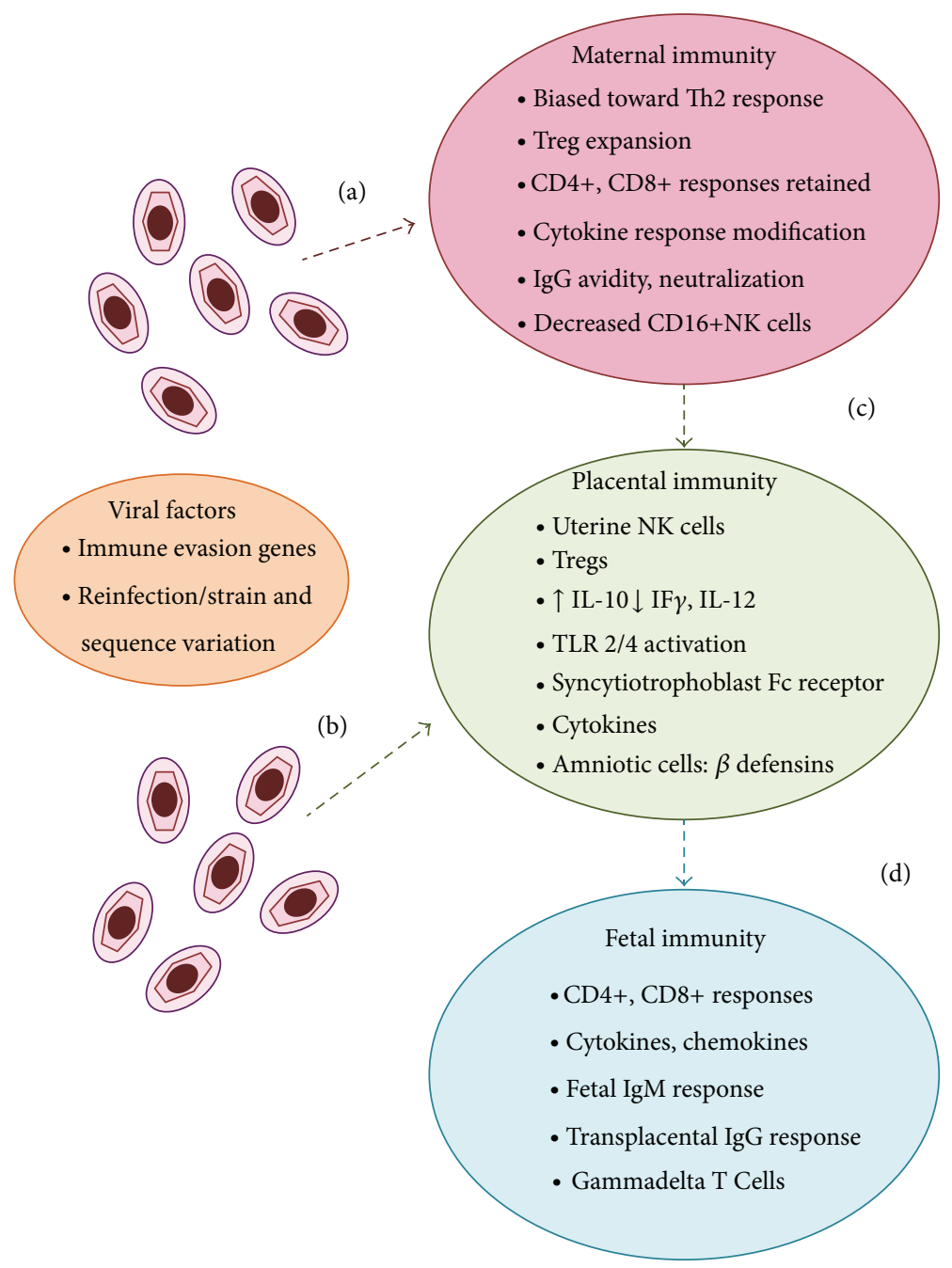

FIGURE 1: Schematic representation of pathways of CMV to the fetus and immune responses potentially important in transmission and prevention. The figure emphasizes the immunological milieu of pregnancy and some of the known immune adaptations associated with pregnancy. Left side of figure, CMV is known both to encode a plethora of immune evasion genes that subvert immune clearance of infection and to demonstrate substantial strain variation that can promote reinfection of already-immune hosts. Virus is believed to reach the placenta via the maternal compartment (a) or ascending infection via local extension in the reproductive tract (b). Although maternal antibody, CD4+, and CD8+ responses are generally intact in pregnancy, there are alterations in Th1/Th2 cytokine balance; alterations in NK cell subpopulations; increased Tregs; and modified cytokine responses. The uterine microenvironment in pregnancy may also play a role in direct local extension of CMV following virus exposure or reactivation (b), driven in part by increased localized IL-10 expression. Irrespective of the route of infection, the immunological profile of the placenta may either facilitate CMV transmission or inhibit it. Factors that may promote transmission include the less efficient killing potential of uNK cells; decreases in cytokines such as IL-12 and IF- $\gamma$; and the potential translocation of CMV particles across the syncytiotrophoblast if low avidity IgG is present. Factors that inhibit transmission include chemokines and $\beta$-defensins and, if present, high avidity neutralizing antibody, which may render virus noninfectious. Once virus enters the fetal compartment, the impaired capacity of fetal CD4+ to proliferate in response to CMV may impair immune control. The presence of transplacentally acquired IgG is believed to ameliorate the severity of disease. There is evidence that CD8+ cells, chemokines, and gammadelta T cells contribute to antiviral immunity in the fetal immune environment.

and a sepsis-like syndrome [14, 19]. It remains unclear whether such postnatal acquisition of infection poses any long-term risk for adverse neurodevelopmental outcomes [20-23].

Although the risks of CMV infection to the developing fetus and neonate are well recognized, the factors that dictate whether or not an infant has an asymptomatic infection or manifests with severe disease are not clear. Immune protection against congenital CMV infection is complex and requires consideration of immune responses in the mother, the fetus, and the placenta (Figure 1). Consideration must also be given to the burgeoning list of virally encoded immune modulation and immune evasion genes, which almost certainly exert a clinically relevant impact on the maternal and fetal immune responses to infection [24]. Another important issue is that of the problem of viral 
strain variation and attendant reinfection, in light of the emerging recognition that maternal antiviral immunity to one strain of CMV may not protect against acquisition of, and subsequent fetal transmission with, a new strain [7, $25,26]$. Development of a vaccine against congenital CMV infection is a major public health priority [27], but most vaccine approaches to date have focused on what is probably an overly simplistic approach: namely, the prevention of primary infection in young women of child-bearing age. Although clearly infection of the fetus cannot occur if maternal infection is prevented by a successful vaccine [28, 29], current vaccine approaches have, by focusing almost exclusively on the prevention of maternal infection, failed to take into consideration the incompletely understood but critically important fetal and newborn immune responses to CMV that may play key roles in preventing CMV end-organ disease and sequelae. Understanding the immune response of the infected fetus may facilitate identification of correlates of protective immunity in the infant. Moreover, it is important to note that many of the CMV vaccines currently in clinical trials are focused on inducing immune responses known to be important in controlling CMV disease in solid organ and hematopoietic stem cell transplant patients, but these effectors of protection in transplant patients may or may not be relevant to the problem of prevention of maternal and fetal CMV infections [30].

Maternal-placental-fetal transmission of CMV occurs against the backdrop of the altered cytokine state of pregnancy, in which there is a functional immune suppression mediated via a shift from a Th1 response to a Th2 bias [31-33]. The altered immune state in pregnancy is likely to be highly relevant to the problem of sustaining vaccinemediated protection against infection and transmission. Issues relevant to the study of the immunology of maternalfetal CMV transmission are germane to the question of the key clinical and immunologic endpoints of vaccine trials, and may help define the most suitable patient population for ultimate administration of a licensed $\mathrm{CMV}$ vaccine against congenital CMV infection. A universal vaccine meant to provide a broad blanket of herd immunity on a population of young children may have different requirements than a vaccine selectively targeting young women of reproductive age. Acceptable attributes of a CMV vaccine in the latter scenario may include not only protection against transmission of infection, but also mediation of protection against CMV disease, even if transmission occurs. Congenital infection commonly occurs in the absence of symptoms or signs of illness, and asymptomatic infants generally have an excellent prognosis for normal neurodevelopment. Thus, better insight into those aspects of the immune response that may contribute to protection against disease in the asymptomatically infected infant might help guide future immunization approaches. This review summarizes recent observations gleaned from the study of the immune response to CMV, focusing on the pregnant woman and developing fetus. The potential application of these studies to immunotherapeutic interventions for prevention of congenital CMV infection and long-term disability is also discussed.

\section{Innate Immunity}

Innate immunity likely plays a crucial role in preventing acquisition of congenital and perinatal CMV infections; conversely, the failure of innate immunity, either due to host genetic factors, the immune tolerance state of pregnancy, and/or viral immune evasion, may contribute to an increased risk of acquisition of infection. Components of the innate immune response in the setting of congenital and perinatal infection include natural killer (NK) cells; toll-like receptors (TLRs); and cytokines. Available information about the role of each of these components in congenital and perinatal CMV infection and transmission is considered below.

2.1. NK Cells. NK cells are important effectors of innate immunity involved in control of viral infection. Human NK cells are typically characterized as CD3-CD56+ lymphocytes that make up about $15 \%$ of peripheral blood lymphocytes. They are further subdivided into CD56 $6^{\text {bright }}$ cells (lacking the expression of CD16 and the killer immunoglobulinlike receptor, KIR) and $\mathrm{CD} 56^{\mathrm{dim}}$ cells, which express CD16 and KIR [34]. NK cells target virally infected cells through perforin and granzyme-mediated cell killing, Fas-ligand initiated apoptosis, and antibody dependent cellular cytotoxicity (ADCC). They also elaborate cytokines and modulate adaptive immune responses via interactions with plasmacytoid dendritic cells $[35,36]$. CMV encodes a number of genes that interfere with the NK cell response. Some of these viral genes encode proteins that alter expression of NK cell receptor ligands, resulting in perturbation of function of the activating receptor, NKG2D; proteins that are homologs of MHC class I that bind the NK cell inhibitory receptor, LIR-1, with a higher affinity than host MHC class I; and proteins that decrease the expression of $\mathrm{CD} 155$, a ligand for NK cell activating receptors [24].

Modulation of the distribution of subtypes of NK cells during pregnancy may have an impact on the risk for acquisition of CMV infection by the placental-fetal unit. During pregnancy, the uterus contains cells known as "uterine NK cells (uNK)" or "decidual NK cells (dNK)". Although these differ from peripheral NK cells, they are in the CD56 $6^{\text {bright }}$ subset of NK cells, and hence have lower cytotoxic ability, similar to peripheral CD56 ${ }^{\text {bright }}$ NK cells [37]. This is one of many different manifestations of the "immune tolerance" state required during pregnancy to prevent rejection of the fetal allograft [38]. During the first trimester of pregnancy, uNK cells are the major population of maternal immune cells, accounting for $~ 70 \%$ immune cells in the decidua, with macrophages, $\mathrm{T}$ cells (CD8+, CD4+, and $\gamma \delta \mathrm{T}$ cells), and dendritic cells accounting for 20,10 , and $2 \%$, respectively [3941]. These uNK cells may compensate for their relative lack of cytotoxic potential by elaboration of antiviral cytokines, particularly interferon gamma, in the uterine microenvironment [42]. It has been reasonably speculated that the lack of an effector phenotype for the uNK cells may contribute to an increased risk of intrauterine CMV transmission [43]. However, it has also been noted that freshly isolated uNK cells can acquire major functional and phenotypic changes 
and can become cytotoxic effectors following exposure to CMV-infected autologous decidual fibroblasts. NKG2D+ and CD94/NKG2C+ or 2E+ activating receptors are involved in the acquisition of cytotoxic function, and these cells in an ex vivo model of CMV-infected trophoblast colocalize with CMV-infected cells [44]. Hence, the cytotoxic potential of these cells following exposure to virus may be important in prevention of CMV transmission in early pregnancy [45].

In addition to the role NK cells play in the placental environment, a suboptimal or deficient NK cell response may play a role in modulating the clinical manifestations and severity of congenital CMV infection. A child with NK cell deficiency was noted to have severe herpesvirus infections, including CMV, although her CMV infection did not appear to be acquired in the perinatal period [46]. A deficiency in NK cell cytotoxic response to herpes simplex virus (HSV)-infected cells was proposed to be a predisposing factor influencing the severity of neonatal HSV infection [47]; whether such mechanisms are relevant for perinatally acquired CMV infection remains to be evaluated. A recent study demonstrated that increased proportions of NK cells expressing the activating killer lectin-like receptor, NKG2C+, were more frequently detected in children with congenital CMV infection. Strikingly, this immunophenotype was more common in symptomatic cases of congenital infection [48], suggesting this as an important correlate of disease outcome. Expansion of NKG2C+ cells also appeared more marked in children with postnatal infection (presumed to be acquired by breastfeeding) than in the group of infants with congenital asymptomatic infection. Based on analogy with studies performed in immune suppressed patients, the authors speculated that the magnitude of the NKG2C+ expansion might be inversely related to the effectiveness of the T-cell response to CMV infection; in other words, that NKG2C+ expansion might reflect inadequate T-cell immunity. Immunophenotyping of NK responses, therefore, might prove useful in assessing prognosis, or identifying infants that would be candidates for immunotherapies. Whether the expansion of NKG2C+ NK cells observed in the setting of symptomatic congenital or perinatal infection contributes to the immunopathogenesis, or conversely the long-term disease control of CMV infection, will require further study.

2.2. Phagocytic Cells. There is relatively little information about the role of phagocytic cells (neutrophils, macrophages) in protection against congenital infection or, in the setting of aberrant function, increased susceptibility to congenital infection. That neutrophils may be important in the first line of defense against vertical transmission of infection is suggested by pathologic studies of CMV-infected placentas demonstrating neutrophilic infiltrates in fetal blood vessels in the villus core [49]. In these studies, placentas with high levels of viral DNA were associated with neutrophilic infiltrations, whereas macrophages and dendritic cells were associated with low levels of DNA; hence, a response biased toward a phagocytic cellular response may be associated with less robust control of infection. Notably, congenital CMV infection does not appear to be associated with heritable abnormalities in neutrophilic oxidative burst, as seen in chronic granulomatous disease [50]. A case of congenital CMV was recently described in a patient with leukocyte adhesion defect type 1 [51], although this infant also had a natural killer cell deficiency, making it unclear to what extent the neutrophil defect contributed to the increased risk of CMV infection. In another case of fulminant congenital $\mathrm{CMV}$, delayed fetal neutrophil differentiation was implicated as a possible contributing factor to the fatal outcome [52].

No cases of congenital CMV infection appear to have been correlated with aberrant macrophage function. However, macrophages do appear to play an as-yet incompletely defined role in modulating vertical transmission of CMV. In CMV infected placentas, marked hyperplasia of fetal-derived placental macrophages, termed Hofbauer cells, has been observed [53]. A serum proteomic comparison of infants with congenital CMV infection and controls demonstrated upregulation of a macrophage-derived chemokine in those infants with CMV infection [54]. It has been suggested that macrophages may potentiate CMV infection and spread in syncytiotrophoblasts. This is based on a cell coculture model system in which the presence of macrophages enhanced activation of CMV in syncytiotrophobast and promoted transmission of virus from cell-to-cell, an effect which was mediated by IL- 8 and TGF- $\beta$ [55]. Macrophages are also themselves targets of CMV infection. Viral antigen was noted in macrophages in a study of term CMV-infected placentas [49]. The ability of CMV to infect macrophages was also demonstrated in a recently described decidual organ culture model [56].

2.3. Toll-Like Receptors (TLRs). There are ten toll-like receptors (TLRs) described in humans [57]. TLRs function to sense microbial pathogens through interactions of pathogenassociated molecular patterns (PAMPs) through their cognate pattern recognition receptors (PRRs), in the process signaling through MyD88-dependent and TRIF-dependent pathways, which in turn upregulates cytokine production [58]. There is evidence that interactions between some members of the TLR family with CMV influence both the immune response to, as well as the outcome of, infection.

TLR2, although typically considered in the context of PAMPs consisting of bacterial polysaccharides, is also a PRR for the CMV envelope glycoproteins, glycoprotein B (gB), and glycoprotein $\mathrm{H}(\mathrm{gH})$. Notably, a polymorphism in the TLR2 gene was shown to be associated with increased CMV replication and an increased risk of CMV disease in liver transplant recipients $[59,60]$. No data exist, however, on whether this TLR2 polymorphism impacts the phenotype of fetal or perinatal CMV disease. CMV-mediated TLR2 signaling was noted to lead to an inflammatory response in a cell culture model utilizing syncytiotrophoblasts, suggesting that this pathway could have some influence on the manifestations of placental-fetal infection in vivo [61, 62]. This signaling occurred in the absence of viral replication, indicating that structural component(s) of the virion may be responsible. These structural components appear to be gB and $\mathrm{gH}$, which have been shown to induce inflammatory cytokine 
secretion in response to CMV exposure, independent of viral replication $[63,64]$. This signaling appears to be mediated by a TLR heterodimer on the infected cell surface, consisting of TLR2 and TLR1 [63].

TLR3 interactions with CMV are related to the binding of double stranded RNA molecules produced during CMV replication [57]. The interrelationship between polymorphisms in TLR3 and susceptibility to herpesvirus disease was demonstrated in studies linking HSV encephalitis to a specific TLR3 polymorphism associated with diminished inflammatory cytokine production following stimulation with an agonist $[65,66]$. This diminished cytokine responsiveness in turn correlated with an increased severity of herpes simplex encephalitis. Recently, an increased susceptibility to CMV infection was proposed for individuals with the $\mathrm{L} 412 \mathrm{~F}$ variant of TLR3 [67]. Peripheral blood mononuclear cells from these patients, who are known to have an increased risk for fungal infections and autoimmunity, were assayed for secretion of cytokines in response to TLR3 ligands and to CMV. Reduced IFN $\gamma$ and TNF $\alpha$ secretion were demonstrated when the $\mathrm{L} 412 \mathrm{~F}$ polymorphism was present. It was inferred that this TLR3 polymorphism conferred an increased risk of CMV disease [67]. On the other hand, no role for TLR3 signaling could be demonstrated during the early immune response of human monocyte-derived dendritic cells after infection with a wild-type isolate of CMV, strain TB40E. This study therefore failed to support a role for CMV-TLR3 interactions in the immunopathogenesis of infection [68].

TLR7 polymorphisms have been suggested to play a role in dictating the magnitude of the immune response to CMV glycoproteins. In a study genotyping 142 women who had been previously vaccinated with three doses of adjuvanted $\mathrm{CMV}$ gB vaccine, it was observed that homozygous carriers of single nucleotide polymorphisms in TLR7 demonstrated a higher vaccination-induced antibody response to $\mathrm{gB}$ than did heterozygotes or homozygotes for this allele [69]. Whether or not TLR7 polymorphisms impact the immune response to $\mathrm{gB}$ in the context of natural CMV infection, or transmission of CMV to the fetus, remains to be evaluated.

2.4. Cytokines, Chemokines, and Defensins. Many cytokines appear to be important in immune control of CMV infection, although defining cytokine(s) that may correlate either with protection or increased susceptibility to infection in the context of congenital or perinatal CMV infection has been difficult in studies reported to date. One difficulty in interpreting studies correlating altered cytokine profiles with an increased CMV infection risk is that such associations may not reflect isolated cytokine perturbations per se, but rather modulation of upstream events that trigger (or diminish) the elaboration of cytokines. These include the TLR polymorphisms already discussed, such as the TLR3 polymorphisms that are associated with decreased proinflammatory cytokine production [67]. Physiologic alterations in cytokine production during pregnancy may contribute to an increased risk of some viral infections. Normal pregnancy is also associated with increased production of IL-10 [70], an anti-inflammatory cytokine, and increased production of this cytokine during pregnancy has been proposed to increase susceptibility to fetal CMV infection [43]. Other cytokines proposed to be important in the context of perinatal viral transmission include TNF- $\alpha$, IL-12, IL-17, IL-18, IL-23, and IL-1 $\beta[43,71]$, although there has been no clear correlation between hereditary deficiencies in any of these cytokines with an increased risk of congenital infection. Similarly, therapeutic monoclonal antibodies targeting TNF- $\alpha$ have not been associated with an increased risk of congenital CMV. However, it has been pointed out that the use of TNF$\alpha$ blocking agents during pregnancy may, by blocking the activity of the TNF superfamily members lymphotoxin- $\alpha$ and $-\beta$, negatively impact the development and organization of secondary lymphoid tissues [72]. A recent analysis of the safety of these agents during pregnancy and lactation suggested an increased risk of infection in infants exposed to these monoclonal antibodies [73], although CMV was not specifically mentioned.

An important consideration in the analysis of the cytokine profile of the congenitally CMV-infected infant is the fact that infant immunocytes produce smaller amounts of cytokines than do comparable adult cells $[74,75]$. Hence, the fetus may be intrinsically at increased risk for CMV infection upon exposure to the virus. A study of cord and adult blood-derived myeloid dendritic cells, following infection with CMV, demonstrated significantly lower levels of IL12 , IFN- $\beta$, and IFN-lambdal production in neonatal cells [76]. On the other hand, another study comparing immune responses between congenitally infected infants and their mothers (who all had serological evidence of primary infection) demonstrated that neonates had significantly higher levels of IL-8, but lower levels of IF- $\gamma$ [77]. Most of the infants in this report were asymptomatic, so the functional consequences of these differences in cytokine profiles with respect to the susceptibility, pathogenesis, and natural history of CMV infection are not clear.

The profile of chemokine and defensin production in the setting of congenital CMV infection has not been extensively studied. One study assayed cytokines and chemokines from midtrimester amniotic fluid in 8 patients giving birth to infants with congenital CMV; midtrimester sera from 12 pregnant women with primary CMV infection; and amniotic fluid and serum from uninfected pregnant controls. This analysis demonstrated that levels of chemokines CCL2, CCL4, and CXCL10 were significantly elevated in amniotic fluid from congenital CMV patients [71]. In this study, only CXCL10 was significantly elevated in the serum of CMVinfected pregnant women, compared to controls. This study did not comment on the chemokine profiles observed in the subset of women with primary CMV infections who did not go on to transmit virus to the fetus. Future studies of amniotic fluid comparing these subgroups would be of considerable interest in elucidating differences between transmitting and nontransmitting mothers. In another study of chemokine production in the CMV-infected placenta, expression of the chemokine MCP-1 was associated with fetal demise [78]. The effect was specific to CMV, insofar as other placental pathogens did not induce MCP-1 hyperexpression. These observations suggested that CMV-induced 
chemokine dysregulation of placental function may be an important indirect contributor to fetal disease, leading to adverse pregnancy outcome even in the absence of fetal infection per se. An interesting study reported by Liu and colleagues used serum proteomic analyses in an attempt to compare protein biomarkers of potential interest in infants with congenital CMV and controls. This study had subgroups of congenitally infected infants who were asymptomatic at birth and compared their proteome profiles to those of symptomatic infants with hepatitis. Thus, this study had the potential to identify candidate biomarkers associated both with a heightened risk of CMV disease or, conversely, protection against disease. Intriguingly, two protein peaks were noted that were upregulated in asymptomatic infants. These protein peaks were interpreted by these investigators, based on molecular weight, as corresponding to $\beta$-defensins 31 and 8 [54]. Further studies to confirm this observation and to better define the role of $\beta$-defensins in protection against congenital CMV infection are warranted.

\section{Adaptive Immunity}

Adaptive immunity in the context of congenital and perinatal CMV infection has clearly been more extensively evaluated than innate immunity. This reflects to a substantial extent the fact that therapeutic interventions based on adaptive immune responses, such as vaccines, are in advanced stages in clinical trials [79]. Adaptive immunity conferred by passive transfer of therapeutic anti-CMV immunoglobulin is also an area of intense clinical research activity $[80,81]$. A number of studies have attempted to elucidate the role of antibody in both protection against congenital CMV transmission and, paradoxically, in promoting transmission of CMV across the syncytiotrophoblast. Evaluation of cellular immune responses has suggested for many years that there is functional impairment of aspects of cell-mediated immunity in infants with CMV infection and their mothers that may be important in transmission and disease progression. These early studies included demonstration of diminished lymphocyte-mediated cytotoxicity in infants with congenital CMV infection and their mothers compared to controls [82] and diminished CMVspecific lymphocyte blastogenesis and interferon production in congenitally infected infants and their mothers [83]. More recent definitive analyses of specific $\mathrm{T}$-cell populations and of immunoglobulins in the context of congenital infection have been undertaken. These studies are reviewed in the following section.

3.1. CD4+ T Cells. The magnitude of the maternal CD4+ Tcell response to CMV infection appears to play an important role in predicting whether virus is transmitted to the fetus. A study of 46 pregnant and 8 nonpregnant women, seropositive for CMV and actively shedding virus in urine, examined the frequency of CMV-specific CD4+ T cells in peripheral blood lymphocytes [84]. Intracellular cytokine staining for IF- $\gamma$ and TNF- $\alpha$ was also performed. There were no changes in the frequencies of CMV-specific CD4+ T cells in CMVseropositive normal nonpregnant and pregnant women at any gestation, although the frequency of CMV-specific CD4+ $\mathrm{T}$ cells was increased in pregnant women with evidence of CMV reactivation or reinfection. There were no congenital CMV infections in these pregnancies, leading these authors to propose that the CD4+ T-cell response can contribute to protection against intrauterine transmission, particularly in the setting of exposure to either reactivated latent virus, or new strains of virus encountered in the setting of re-infection. Another prospective study examined CMV-specific lymphoproliferative response and intracellular cytokine (IFN- $\gamma$ and IL-2) production during the first year after primary infection in 49 pregnant women and 9 nonpregnant controls. During the first month after infection, IFN $-\gamma$ producing CD $4+$ and CD8+ T cells were uniformly present, whereas IL2-producing $\mathrm{T}$ cells were very rarely detected. Notably, a significantly delayed development of the CD4+ T-cell lymphoproliferative response was observed in infected mothers who transmitted virus to the fetus, compared with women who did not transmit [85].

Another study of 74 pregnant women and 29 nonpregnant controls with primary CMV infection enumerated CMVspecific CD4+ cells by cytokine flow cytometry and lymphoproliferative responses [86]. A significantly lower median stimulation index was observed in the 19 women who transmitted the virus than in the 21 women who did not. No other immunologic (IgM response, IgG antibody avidity) or virologic marker (magnitude of DNAemia) was predictive of transmission. Similar observations regarding the importance of the lymphoproliferative response to CMV have been noted by other investigators $[87,88]$. These observations suggest that interventions designed to maximize the maternal CMVspecific lymphoproliferative CD4+ response may be useful in protection against congenital CMV infection. Other studies have examined the pattern of CMV-specific T-cell responses in pregnant women during the first year after acquisition of a primary infection, compared to those of pregnant women with prior preconception immunity to CMV. These analyses demonstrated that, in addition to the delayed lymphoproliferative response in CMV-transmitting mothers, there was also a significant delay in the reversion of CMV-specific effector memory T cells to the CD45RA+ phenotype [89, 90]. These investigators proposed that examination of CD45RA reexpression might be an important prognostic parameter in the setting of maternal-fetal transmission.

In addition to the importance of maternal CD4+ responses in CMV transmission, CD4+ responses in the fetus and newborn in the context of vertical transmission may also play a role in predicting the outcome of congenital infection. $\mathrm{CD} 4+$ responses to $\mathrm{CMV}$ infection in young children are of substantially diminished magnitude compared to adults. Young children have a selective and long-lived deficiency in CD4+ T cell immunity characterized by decreased IF- $\gamma$ and IL-2 production. It was postulated that this suboptimal CD4+ response might be responsible for the prolonged shedding of CMV observed in infants following acquisition of CMV infection [91]. In this study, these young children had no symptoms of CMV disease and had presumably acquired infection from breastfeeding or attendance in group day care. 
In addition to the study of CD4+ responses in pregnant women and young children with post-natally acquired infections, the CD4+ responses of the CMV-infected fetus has been evaluated in several studies. These analyses suggest that the magnitude of the CD4+ response in the fetus may not play a significant role in protection, and in fact may correlate with the severity of CMV disease. In a study of perinatal CMV infection in a high seroprevalence population, the frequencies of CMV-specific CD4+ T cells detected by intracellular cytokine staining for IF- $\gamma$ and TNF- $\alpha$ were higher in infants with symptomatic congenital infection than in those infants with asymptomatic perinatal infection [92]. This could, of course, simply reflect a more intense infection with higher viral load and not a deleterious effect of the cytokine response per se. The authors suggested that monitoring these immunological markers could be useful in predicting the prognosis of congenital CMV infection.

Not all studies have readily demonstrated fetal/neonatal CD4+ responses in the setting of congenital infection. A study of seven patients with congenital CMV infection, six healthy infants who had acquired infection postnatally, and six CMV-seropositive adults found a striking paucity of CMV-specific IF- $\gamma$-producing CD4+ cells in congenitally infected infants, compared to the healthy infant and adult controls with CMV infection; however, the congenitally infected infants in this study were asymptomatic, so this study did not exclude a relationship between CD4+ response and symptomatic disease [93]. Another recent study compared Tcell responses in 24 children with congenital CMV infection (9 symptomatic), 19 children with postnatal CMV infection, and 8 adults with symptomatic primary CMV infection. Compared to adults, CMV-specific CD4+ T-cell responses in children younger than 2 years were low or undetectable, although they did appear to increase over time. No differences were noted with regard to $\mathrm{CD} 8+\mathrm{T}$-cell responses, and no differences were noted comparing symptomatic and asymptomatic children. These authors concluded that the inadequate response of $\mathrm{CD} 4+$ cells is a major factor responsible for lack of immune control of CMV infections in infants and young children [94]. It is of interest to reflect on these observations in light of a recent study demonstrating a striking inhibitory effect of CMV particles on CD4+ T-cell proliferation, concomitant with decreased levels of cytokines IL-4, IFN- $\gamma$, and TNF- $\alpha$ in cell culture [95].

An interesting subset of CD4+ cells are known as regulatory $\mathrm{T}$ cells (Tregs). These cells are critical to the maintenance of immune cell homeostasis by mediating a dominant negative regulation on other immune cells. These cells can be broadly classified into natural or adaptive (induced) Tregs. "Natural" Tregs are CD4+CD25+ T cells which develop in and emigrate from the thymus to maintain immune homeostasis, maintain tolerance to self-antigens, and abrogate autoimmune disease. "Adaptive" Tregs are nonregulatory $\mathrm{CD} 4+\mathrm{T}$ cells which acquire CD25 expression outside of the thymus and are typically induced by inflammation and disease processes. Expansion of Tregs is important in the maintenance of normal pregnancy and contributes to the protection of the fetus from the maternal immune response $[96,97]$. However, Tregs may also block beneficial immune responses by preventing development of sterilizing immunity to viruses $[98,99]$. The role that Tregs play in susceptibility to or protection against fetal CMV infection has not been investigated. A recent analysis of Tregs during CMV replication in solid organ transplant recipients demonstrated that lower Tregs were observed in patients with spontaneous clearance of virus after transplantation and that the ratio of CMV-specific T cells to Tregs was highly predictive of relapse [100]. Treg-mediated suppression of anti-CMV responses was observed in a study in which Tregs were depleted from peripheral blood mononuclear cells prior to measurement of IF- $\gamma$ production. In this study, CD8+ T cells produced more IF- $\gamma$ in the absence of Tregs [101]. Following hematopoietic stem cell transplantation, Tregs do not appear to inhibit CMV clearance by conventional T cells [102]. The relevance of these observations to the role of Tregs in modulation of fetal and neonatal CMV infection remains to be examined.

3.2. CD8+ T Cells. Primary infection with CMV in immunocompetent hosts is accompanied by activation and differentiation of naïve CD8+ T cells, which become effector/memory cells capable of secreting IFN- $\gamma$ and attacking and lysing infected target cells [103]. Studies examining the specific virally-encoded targets of CD8+ T cells have demonstrated that there is a broad and diverse repertoire of responses to many viral peptides, although reactivity against CMV proteins pp65 (ppUL83) and IE-1 appear to be of the greatest importance in control of CMV disease [104-106]. Healthy CMV-seropositive individuals devote approximately $10 \%$ of the total memory T-cell pool in the peripheral blood to CD8+ cells specific for CMV antigens [107].

CD8+ responses are readily generated following CMV infection both in young children and by the fetus in utero. CD8+ responses in young infants, compared to adults, are known to demonstrate focused peptide specificity and lower peptide avidity, although the peptide specificity does broaden over time [108]. The development of CD8+ responses in the setting of perinatal/congenital CMV infection has been examined by a number of groups. To attempt to elucidate the role of CD8+ responses in protection against congenital CMV infection, Pédron et al. examined 16 transmitter mothers who underwent seroconversion during the first trimester of pregnancy and their fetuses (all were positive for CMV in amniotic fluid by PCR at 17-19 weeks of gestation). Fetal and maternal blood samples were collected between the 22nd and 39 th week of gestation. Activation, effector, and memory phenotypes were compared, and IF- $\gamma$ secretion was examined. The responses were generally similar, although there was a smaller pp65-specific pool in the fetus, and fetal CTLs made less IF- $\gamma$ in response to stimulation with a CD3 monoclonal antibody [109]. Another study in $15 \mathrm{CMV}$-infected fetuses demonstrated CD8+ responses as early as the 22nd week of gestation. Compared with controls, CMV-infected fetuses demonstrated a dramatic increase in activated and terminally differentiated CD8+ T cells [110]. However, these authors noted that cellular immunity to CMV did not appear to be fully functional, evidenced by the fact that the number of $\mathrm{T}$ cells capable of secreting IFN- $\gamma$ was substantially 
TABLE 1: Summary of innate immune responses and their proposed role in control of or susceptibility to congenital CMV infection.

\begin{tabular}{|c|c|c|}
\hline \multicolumn{3}{|c|}{ Innate immunity and susceptibility/protection in congenital CMV infection } \\
\hline Immune effector & $\begin{array}{l}\text { Maternal/placental/fetal } \\
\text { compartment }\end{array}$ & Proposed effect on CMV transmission/disease \\
\hline $\begin{array}{l}\text { NK } \\
\text { cells-CD56 } 6^{\text {bright }}\end{array}$ & $\begin{array}{l}\text { Maternal (pregnancy) } \\
\text { Uterine NK cells }\end{array}$ & $\begin{array}{l}\text { (i) Decreased cytolytic potential } \\
\text { (ii) Increased risk of CMV transmission? }\end{array}$ \\
\hline $\begin{array}{l}\text { NK } \\
\text { cells-NKG2C+ }\end{array}$ & Fetal compartment & $\begin{array}{l}\text { (i) Expansion of this NK subset in congenital and perinatal CMV } \\
\text { (ii) Correlation with symptomatic CMV disease? }\end{array}$ \\
\hline Phagocytic cells & Placental compartment & $\begin{array}{l}\text { (i) Neutrophils: possible role in defense } \\
\text { (ii) Macrophage: potentiates spread to syncytiotrophoblasts? }\end{array}$ \\
\hline $\begin{array}{l}\text { Toll-like } \\
\text { receptors }\end{array}$ & $\begin{array}{l}\text { Maternal compartment } \\
\text { Placental compartment }\end{array}$ & $\begin{array}{l}\text { (i) TLR2 polymorphism; } \downarrow \text { signaling to CMV glycoproteins; } \uparrow \text { risk of CMV disease } \\
\text { in transplant patients; increased transmission risk? } \\
\text { (ii) TLR3 polymorphism; decreased signaling to CMV antigens } \\
\text { (iii) TLR7 polymorphism: decreased antibody response to glycoprotein B? }\end{array}$ \\
\hline $\begin{array}{l}\text { Cytokines } \\
\text { Chemokines } \\
\text { Defensins }\end{array}$ & $\begin{array}{l}\text { Neonatal compartment } \\
\text { Maternal compartment } \\
\text { Placental compartment } \\
\text { Placental-fetal interface }\end{array}$ & $\begin{array}{l}\text { (i) } \uparrow \text { IL- } 8 \downarrow \text { IF- } \gamma \text { may correlate with increased transmission risk } \\
\text { (ii) Increased maternal CCL-10 correlates with transmission } \\
\text { (iii) Increased placental MCP-1 expression correlates with fetal demise } \\
\text { (iv) Physiological increase in uterine IL-10 in pregnancy: increased risk of } \\
\text { reactivation/transmission? } \\
\text { (v) Beta-defensins } 8 \text { and } 31 \text { proposed to be upregulated in amniotic fluid of } \\
\text { asymptomatically congenitally infected infants }\end{array}$ \\
\hline
\end{tabular}

lower after in vitro stimulation with CMV antigen than after exposure to stimulants such as phorbol myristate and ionomycin.

Although these studies raise questions about the functionality of $\mathrm{CMV}$-specific $\mathrm{CD} 8+$ responses generated in utero, a study lead by Marchant and colleagues examining 8 infants with congenital infection and 15 uninfected controls demonstrated the expansion and the differentiation of mature CMV-specific CD8+ cells with similar characteristics to those detected in adults. These cells demonstrated potent perforindependent cytolytic activity and produced abundant amounts of antiviral cytokines, particularly IF- $\gamma$ [111]. These data support the concept of a potentially protective role for the development of fetal antiviral CD8+ T-cell responses in the control of CMV disease. These observations also suggest the provocative possibility of designing and developing prenatal vaccination strategies toward the goal of priming fetal immunity against CMV, as well as for other viral diseases $[112,113]$. Further studies are clearly required to define the role of CD8+ cells-engendered both in the maternal and fetal compartments-in protection against congenital CMV infection.

3.3. Gammadelta T Cells. Gammadelta T cells are unconventional $\mathrm{T}$ cells that do not require antigen processing and major histocompatibility-complex presentation of peptide epitopes and, accordingly, can react rapidly upon activation [114]. These cells demonstrate features of both adaptive and innate cells and are described as a "bridge" between innate and adaptive immunity. A study of CMV-infected fetuses demonstrated that fetal gammadelta $\mathrm{T}$ cells are capable of expansion and differentiation [115]. Differentiated gammadelta $\mathrm{T}$ cells expressed high levels of IFN- $\gamma$, natural killer cell receptors, and other cytokines, and demonstrated antiviral activity. Differentiated gammadelta $\mathrm{T}$ cells could be detected as early as after 21 weeks of gestation. The extent to which this T-cell subset participates in antiviral defense in utero and in early life requires further investigation.

3.4. Antibody. Of all the immune effectors studied in the context of congenital and perinatal CMV transmission, perhaps the most studied are anti-CMV antibodies. This is driven in part by the intense interest in adjuvanted glycoprotein subunit vaccines engendered by recent clinical trials designed to elicit a protective antibody response against CMV gB. In both young women of childbearing age [116] as well as in solid organ transplant recipients [117], a CMV vaccine based on purified subunit gB demonstrated some degree of protection against acquisition of CMV infection. The fact that the $\mathrm{gB}$ vaccine was also capable of boosting antibody titers when administered to women who already had CMV antibody from previous infection suggests that a vaccine strategy of immunizing seropositives might be able to prevent reinfection with and subsequent transmission of new CMV strains in women with prior immunity $[118,119]$. These successes notwithstanding, the role that anti-CMV antibody response plays in protection of the fetus remains incompletely understood. Notably, there is not known to be an increased incidence of congenital CMV infection in the setting of humoral immunodeficiencies, suggesting that antibody is not absolutely required for protection. However, a case of congenital CMV infection was recently reported in a woman receiving the anti-B cell monoclonal antibody, rituximab [120], suggesting that the inability to sustain a humoral response to CMV may confer an increased risk of transmission in some patients. Rituximab has also been associated with serious CMV disease in a patient on maintenance therapy [121].

Although antibody plays an important role in protection against CMV infection and disease, the level of protection 
TABLE 2: Summary of adaptive immune responses and their proposed role in control of or susceptibility to congenital CMV infection.

Adaptive immunity and susceptibility/protection in congenital CMV infection Immune effector $\begin{aligned} & \text { Maternal/placental/fetal Proposed effect on CMV transmission/disease } \\ & \text { compartment }\end{aligned}$

(i) Delayed development of CD4+ T-cell lymphoproliferative response correlates with maternal-fetal transmission

CD4+ T cells $\quad$ Maternal compartment

(ii) Defective CD4+ immunity; diminished IF- $\gamma$ and IL-2 production in fetal and early childhood infection

compartment

(iii) Defective fetal CD4+ response may contribute to congenital CMV infection and disease

\begin{tabular}{|c|c|c|}
\hline T-regs & Maternal compartment & $\begin{array}{l}\text { (i) Treg expansion: normal response to pregnancy } \\
\text { (ii) } \downarrow \text { Tregs: correlates with protection against CMV disease in transplant recipients } \\
\text { (iii) Relevance to congenital CMV unknown }\end{array}$ \\
\hline CD8+ T cells & $\begin{array}{l}\text { Maternal compartment } \\
\text { Fetal/neonatal } \\
\text { compartment }\end{array}$ & $\begin{array}{l}\text { (i) CD8+ response to infection appears unaltered in pregnancy } \\
\text { (ii) Fetal CD8+ response to CMV antigens noted as early as week } 22 \text { gestation } \\
\text { (iii) Exhibit cytolytic properties and elucidate IF- } \gamma \\
\text { (iv) Some studies raise questions about functionality? }\end{array}$ \\
\hline Gammadelta T cells & Neonatal compartment & $\begin{array}{l}\text { (i) Fetal gammadelta T cells differentiate and expand in setting of congenital CMV } \\
\text { infection } \\
\text { (ii) Produce IF- } \gamma \text { and other cytokines } \\
\text { (iii) Role in protection of fetus, control of virus not clear }\end{array}$ \\
\hline Antibody & $\begin{array}{l}\text { Maternal compartment } \\
\text { Placental compartment } \\
\text { Fetal compartment }\end{array}$ & $\begin{array}{l}\text { (i) Variability in maternal antibody response based on viral strain variation, } \\
\text { possibly TLR polymorphisms } \\
\text { (ii) Expression of neonatal Fc receptor may paradoxically promote transcytosis of } \\
\text { CMV particles across syncytiotrophoblast by low-avidity antibody } \\
\text { (iii) High avidity antibody may neutralize CMV at placental interface } \\
\text { (iv) Transplacental transfer of therapeutic neutralizing antibody may improve } \\
\text { outcome of infected fetus }\end{array}$ \\
\hline
\end{tabular}

is clearly incomplete. Notably, CMV can readily infect the newborn infant, via ingestion of breast milk, even in the setting of passively acquired maternal antibody [17, 107]. Moreover, CMV reinfection of the pregnant woman with subsequent transmission to the fetus, as noted earlier, can occur even in the setting of preexisting maternal immunity $[7$, $122,123]$. These shortcomings aside, there is an emerging role for IgG as an immunotherapy for prevention and treatment of congenital CMV. A study of administration of CMVspecific hyperimmune globulin to pregnant women appeared to significantly lower the risk of congenital CMV infection and disease, although given the uncontrolled nature of the study, conclusions about the mechanism of protection could not be definitively drawn $[124,125]$. The extent to which antibody therapy reverses established CMV disease in the infected fetus or prevents sequelae is uncertain, although some studies to date are very encouraging, suggesting both short-term [126] and long-term [127] benefits. The beneficial effect of immune globulin is proposed to be mediated by virus neutralization in the CMV-infected fetus, although it is possible that the benefit of IgG may be via another mechanism. The major target of the neutralizing antibody response in CMV hyperimmune globulin is directed at proteins in the gH/gL/UL128/UL130/UL131 complex [128], and if ongoing trials confirm a protective/therapeutic effect of hyperimmune globulin administration to pregnant women at high risk of CMV transmission to their fetuses [129], antibodies to this complex may emerge as an important serological correlate of protection.
In addition to providing a protective/therapeutic effect for the CMV-infected fetus, antibody appears to exert protection at the level of the placenta. In an ultrasonographic assessment of placental thickness, women with primary CMV infection who had a fetus or newborn with CMV disease had placentas that were significantly thicker than those of women with primary CMV infection who did not have a diseased fetus or newborn; moreover, receipt of hyperimmune globulin was associated with statistically significant reductions in placental thickness [130]. Immunohistochemical analyses also supported a benefit of IgG on placental health [131]. On the other hand, CMV antibody may, paradoxically, promote transmission of virus to the fetus, via the expression of the neonatal Fc receptor on syncytiotrophoblast. It has been shown that antibody-virus complexes can translocate the syncytial barrier via this receptor, allowing entry of virus into the fetal circulation [132]. In this model, virus transmission can be interrupted if the antibody is of sufficiently high neutralizing capacity and avidity. Viral transmission from mother to fetus may be increased if the maternal antibody response is of low avidity or of poor neutralizing activity.

There is relatively little information about the ability of the infected fetus to mount an independent antibody response to CMV infection. The infected fetus generates IgM antibodies to CMV but the antiviral activity, if any, of such antibodies has not been evaluated. CMV IgM antibodies can be measured in the newborn as an adjunct to other diagnostic studies [133] but it is unknown if they play any role in disease control. 


\section{Summary}

In summary, there is limited information about the precise protective correlates of anti-CMV immunity in the setting of congenital and perinatal infection, although the increasing availability of cohorts of congenitally infected infants has enabled some research into the fetal and neonatal immune response in recent years. Protection of the fetus cannot be assured in the setting of maternal immunity, since reinfection with a novel strain of CMV can occur, with transmission to the fetus. Viral strain variation may contribute to reinfection, and low maternal IgG avidity may paradoxically promote transmission of virus across the syncytiotrophoblast, via the neonatal Fc receptor. Other immune mechanisms operating at the level of the placenta, particularly innate immunity, may play a more important role than antibody in limiting infection of the fetus. The physiological state of pregnancy may impair some aspects of the immune response to CMV, predisposing to placental and fetal infection. Tables 1 and 2 provide a summary of available information regarding the potential protective and predisposing parameters of innate and adaptive immune responses associated with CMV transmission. Importantly, the fetus can mount an immune response to $\mathrm{CMV}$, although the role that this response plays in limiting the extent of CMV-associated disease or sequelae remains uncertain and requires further investigation. It is conceivable that novel vaccines and immunotherapies could exploit aspects of innate and adaptive immunity known to correlate with protection. These should be considered in ongoing vaccine design. It is also important to keep in perspective that not all congenital infections result in disease and/or sequelae. Prospective natural history studies that define the immune correlates associated with protection against transmission and/or protection of the newborn from progression to CMV disease are needed. Since most congenitally infected infants are asymptomatic and have a good prognosis for normal neurodevelopmental outcome, comparing the immunological profile of asymptomatic infants to those with disease and/or sequelae is a high-priority area for future research. These observations could in turn provide opportunities for the design and development of effective interventions to help address this unsolved public health problem.

\section{Acknowledgments}

Support by grants R01HD044864 and R01HD038416 from the NIH is acknowledged.

\section{References}

[1] A. Kenneson and M. J. Cannon, "Review and meta-analysis of the epidemiology of congenital cytomegalovirus (CMV) infection," Reviews in Medical Virology, vol. 17, no. 4, pp. 253276, 2007.

[2] C. Wang, X. Zhang, S. Bialek, and M. J. Cannon, "Attribution of congenital cytomegalovirus infection to primary versus nonprimary maternal infection," Clinical Infectious Diseases, vol. 52, no. 2, pp. ell-e13, 2011.
[3] J. L. Nyholm and M. R. Schleiss, "Prevention of maternal cytomegalovirus infection: current status and future prospects," International Journal of Women's Health, vol. 2, no. 1, pp. 23-35, 2010.

[4] S. E. Oliver, G. A. Cloud, P. J. Sánchez et al., "Neurodevelopmental outcomes following ganciclovir therapy in symptomatic congenital cytomegalovirus infections involving the central nervous system," Journal of Clinical Virology, vol. 46, supplement 4, pp. S22-S26, 2009.

[5] R. J. Whitley, "Congenital cytomegalovirus infection: epidemiology and treatment," Advances in Experimental Medicine and Biology, vol. 549, pp. 155-160, 2004.

[6] K. B. Fowler, S. Stagno, and R. F. Pass, "Maternal immunity and prevention of congenital cytomegalovirus infection," Journal of the American Medical Association, vol. 289, no. 8, pp. 1008-1011, 2003.

[7] A. Y. Yamamoto, M. M. Mussi-Pinhata, S. B. Boppana et al., "Human cytomegalovirus reinfection is associated with intrauterine transmission in a highly cytomegalovirus-immune maternal population," American Journal of Obstetrics and Gynecology, vol. 202, no. 3, pp. 297.e1-297.e8, 2010.

[8] E. C. Swanson and M. R. Schleiss, "Congenital cytomegalovirus infection: new prospects for prevention and therapy," Pediatric Clinics of North America, vol. 60, no. 2, pp. 335-349, 2013.

[9] B. N. Bristow, K. A. O’Keefe, S. C. Shafir, and F. J. Sorvillo, "Congenital cytomegalovirus mortality in the United States, 1990-2006," PLoS Neglected Tropical Diseases, vol. 5, no. 4, Article ID el140, 2011.

[10] K. B. Fowler, S. Stagno, R. F. Pass, W. J. Britt, T. J. Boll, and C. A. Alford, "The outcome of congenital cytomegalovirus infection in relation to maternal antibody status," The New England Journal of Medicine, vol. 326, no. 10, pp. 663-667, 1992.

[11] M. Lanari, M. G. Capretti, T. Lazzarotto et al., "Neuroimaging in CMV congenital infected neonates: how and when," Early Human Development, vol. 88, supplement 2, pp. S3-S5, 2012.

[12] M. R. Schleiss, "Congenital cytomegalovirus infection: molecular mechanisms mediating viral pathogenesis," Infectious Disorders, vol. 11, no. 5, pp. 449-465, 2011.

[13] K. Hamprecht, S. Witzel, J. Maschmann, C. P. Speer, and G. Jahn, "Transmission of cytomegalovirus infection through breast milk in term and preterm infants: the role of cell free milk whey and milk cells," Advances in Experimental Medicine and Biology, vol. 478, pp. 231-239, 2000.

[14] J. Maschmann, K. Hamprecht, K. Dietz, G. Jahn, and C. P. Speer, "Cytomegalovirus infection of extremely low-birth weight infants via breast milk," Clinical Infectious Diseases, vol. 33, no. 12, pp. 1998-2003, 2001.

[15] R. A. Bowden, S. J. Slichter, M. Sayers et al., "A comparison of filtered leukocyte-reduced and cytomegalovirus (CMV) seronegative blood products for the prevention of transfusionassociated CMV infection after marrow transplant," Blood, vol. 86, no. 9, pp. 3598-3603, 1995.

[16] M. Dworsky, M. Yow, S. Stagno, R. F. Pass, and C. Alford, "Cytomegalovirus infection of breast milk and transmission in infancy," Pediatrics, vol. 72, no. 3, pp. 295-299, 1983.

[17] M. R. Schleiss, "Acquisition of human cytomegalovirus infection in infants via breast milk: natural immunization or cause for concern?" Reviews in Medical Virology, vol. 16, no. 2, pp. 7382,2006

[18] T. M. Lanzieri, S. C. Dollard, C. D. Josephson, D. S. Schmid, and S. R. Bialek, "Breast milk-acquired cytomegalovirus infection 
and disease in VLBW and premature infants," Pediatrics, vol. 131, no. 6, pp. e1937-e1945, 2013.

[19] P. Gessler, G. A. Bischoff, D. Wiegand, B. Essers, and W. Bossart, "Cytomegalovirus-associated necrotizing enterocolitis in a preterm twin after breastfeeding," Journal of Perinatology, vol. 24, no. 2, pp. 124-126, 2004.

[20] J. Nijman, L. S. de Vries, C. Koopman-Esseboom, C. S. P. M. Uiterwaal, A. M. van Loon, and M. A. Verboon-Maciolek, "Postnatally acquired cytomegalovirus infection in preterm infants: a prospective study on risk factors and cranial ultrasound findings," Archives of Disease in Childhood, vol. 97, no. 4, pp. F259-F263, 2012.

[21] M. G. Capretti, M. Lanari, T. Lazzarotto et al., "Very low birth weight infants born to cytomegalovirus-seropositive mothers fed with their mother's milk: a prospective study," The Journal of Pediatrics, vol. 154, no. 6, pp. 842-848, 2009.

[22] A. Bevot, K. Hamprecht, I. Krägeloh-Mann, S. Brosch, R. Goelz, and B. Vollmer, "Long-term outcome in preterm children with human cytomegalovirus infection transmitted via breast milk," Acta Paediatrica, vol. 101, no. 4, pp. el67-el72, 2012.

[23] B. Vollmer, K. Seibold-Weiger, C. Schmitz-Salue et al., "Postnatally acquired cytomegalovirus infection via breast milk: effects on hearing and development in preterm infants," Pediatric Infectious Disease Journal, vol. 23, no. 4, pp. 322-327, 2004.

[24] M. Miller-Kittrell and T. E. Sparer, "Feeling manipulated: cytomegalovirus immune manipulation," Virology Journal, vol. 6, article 4, 2009.

[25] M. M. Mussi-Pinhata, A. Y. Yamamoto, R. M. M. Brito et al., "Birth prevalence and natural history of congenital cytomegalovirus infection in a highly seroimmune population," Clinical Infectious Diseases, vol. 49, no. 4, pp. 522-528, 2009.

[26] S. B. Boppana, K. B. Fowler, W. J. Britt, S. Stagno, and R. F. Pass, "Symptomatic congenital cytomegalovirus infection in infants born to mothers with preexisting immunity to cytomegalovirus," Pediatrics, vol. 104, no. 1, pp. 55-60, 1999.

[27] H. Sung and M. R. Schleiss, "Update on the current status of cytomegalovirus vaccines," Expert Review of Vaccines, vol. 9, no. 11, pp. 1303-1314, 2010.

[28] P. D. Griffiths, "Burden of disease associated with human cytomegalovirus and prospects for elimination by universal immunisation," The Lancet Infectious Diseases, vol. 12, no. 10, pp. 790-798, 2012.

[29] J. Johnson, B. Anderson, and R. F. Pass, "Prevention of maternal and congenital cytomegalovirus infection," Clinical Obstetrics and Gynecology, vol. 55, no. 2, pp. 521-530, 2012.

[30] M. R. Schleiss, "Cytomegalovirus vaccine development," Current Topics in Microbiology and Immunology, vol. 325, pp. 361$382,2008$.

[31] T. G. Wegmann, H. Lin, L. Guilbert, and T. R. Mosmann, "Bidirectional cytokine interactions in the maternal-fetal relationship: is successful pregnancy a TH2 phenomenon?" Immunology Today, vol. 14, no. 7, pp. 353-356, 1993.

[32] L. Sykes, D. A. MacIntyre, X. J. Yap, T. G. Teoh, and P. R. Bennett, "The Th1:th2 dichotomy of pregnancy and preterm labour," Mediators of Inflammation, vol. 2012, Article ID 967629, 12 pages, 2012.

[33] L. Sykes, D. A. MacIntyre, X. J. Yap, S. Ponnampalam, T. G. Teoh, and P. R. Bennett, "Changes in the Th1:Th2 cytokine bias in pregnancy and the effects of the anti-inflammatory cyclopentenone prostaglandin 15-deoxy-Delta ${ }^{12,14}$-prostaglandin $\mathrm{J}_{2}$," Mediators of Inflammation, vol. 2012, Article ID 416739, 12 pages, 2012.
[34] S. Jost and M. Altfeld, "Control of human viral infections by natural killer cells," Annual Review of Immunology, vol. 31, pp. 163-194, 2013.

[35] J. G. O'Leary, M. Goodarzi, D. L. Drayton, and U. H. von Andrian, "T cell- and B cell-independent adaptive immunity mediated by natural killer cells," Nature Immunology, vol. 7, no. 5, pp. 507-516, 2006.

[36] E. Vivier, E. Tomasello, M. Baratin, T. Walzer, and S. Ugolini, "Functions of natural killer cells," Nature Immunology, vol. 9, no. 5, pp. 503-510, 2008.

[37] G. E. Lash, S. C. Robson, and J. N. Bulmer, "Review: functional role of uterine natural killer ( $\mathrm{uNK}$ ) cells in human early pregnancy decidua," Placenta, vol. 31, supplement, pp. S87-S92, 2010.

[38] J. Trowsdale and A. G. Betz, "Mother's little helpers: mechanisms of maternal-fetal tolerance," Nature Immunology, vol. 7, no. 3, pp. 241-246, 2006.

[39] I. Manaster and O. Mandelboim, "The unique properties of uterine NK cells," American Journal of Reproductive Immunology, vol. 63, no. 6, pp. 434-444, 2010.

[40] I. Manaster, S. Mizrahi, D. Goldman-Wohl et al., "Endometrial NK cells are special immature cells that await pregnancy," Journal of Immunology, vol. 181, no. 3, pp. 1869-1876, 2008.

[41] P. F. Whitelaw and B. A. Croy, "Granulated lymphocytes of pregnancy," Placenta, vol. 17, no. 8, pp. 533-543, 1996.

[42] T. Strowig, F. Brilot, and C. Münz, "Noncytotoxic functions of NK cells: direct pathogen restriction and assistance to adaptive immunity," Journal of Immunology, vol. 180, no. 12, pp. 77857791, 2008.

[43] W. J. Muller, C. A. Jones, and D. M. Koelle, "Immunobiology of herpes simplex virus and cytomegalovirus infections of the fetus and newborn," Current Immunology Reviews, vol. 6, no. 1, pp. 38-55, 2010.

[44] J. Siewiera, H. El Costa, J. Tabiasco et al., "Human cytomegalovirus infection elicits new decidual natural killer cell effector functions," PLoS Pathogens, vol. 9, no. 4, Article ID 100325, 2013.

[45] P. Le Bouteiller, J. Siewiera, Y. Casart et al., "The human decidual NK-cell response to virus infection: what can we learn from circulating NK lymphocytes?" Journal of Reproductive Immunology, vol. 88, no. 2, pp. 170-175, 2011.

[46] C. A. Biron, K. S. Byron, and J. L. Sullivan, "Severe herpesvirus infections in an adolescent without natural killer cells," The New England Journal of Medicine, vol. 320, no. 26, pp. 1731-1735, 1989.

[47] S. Kohl, J. J. Frazier, S. B. Greenberg, L. K. Pickering, and L. S. Loo, "Interferon induction of natural killer cytotoxicity in human neonates," The Journal of Pediatrics, vol. 98, no. 3, pp. 379-384, 1981.

[48] D. E. Noyola, C. Fortuny, A. Muntasell et al., "Influence of congenital human cytomegalovirus infection and the NKG2C genotype on NK-cell subset distribution in children," European Journal of Immunology, vol. 42, no. 12, pp. 3256-3266, 2012.

[49] S. McDonagh, E. Maidji, H.-T. Chang, and L. Pereira, "Patterns of human cytomegalovirus infection in term placentas: a preliminary analysis," Journal of Clinical Virology, vol. 35, no. 2, pp. 210-215, 2006.

[50] P. G. Quie, J. G. White, B. Holmes, and R. A. Good, "In vitro bactericidal capacity of human polymorphonuclear leukocytes: diminished activity in chronic granulomatous disease of childhood," The Journal of Clinical Investigation, vol. 46, no. 4, pp. 668-679, 1967. 
[51] N. Rai and N. Thakur, "Congenital CMV with LAD type 1 and NK cell deficiency," Journal of Pediatric Hematology/Oncology, vol. 35, no. 6, pp. 468-469, 2013.

[52] A. Salvador, D. Najjar, and H. Hurt, "A preterm infant with a fatal congenital cytomegalovirus CMV infection," Journal of Perinatology, vol. 10, no. 2, pp. 228-229, 1990.

[53] D. A. Schwartz, R. Khan, and B. Stoll, "Characterization of the fetal inflammatory response to cytomegalovirus placentitis," Archives of Pathology \& Laboratory Medicine, vol. 116, no. 1, pp. 21-27, 1992.

[54] Z. Liu, Y. Tian, B. Wang et al., "Serum proteomics with SELDITOF-MS in congenital human cytomegalovirus hepatitis," Journal of Medical Virology, vol. 79, no. 10, pp. 1500-1505, 2007.

[55] A. Bácsi, J. Aranyosi, Z. Beck et al., "Placental macrophage contact potentiates the complete replicative cycle of human cytomegalovirus in syncytiotrophoblast cells: role of interleukin- 8 and transforming growth factor- $\beta 1$," Journal of Interferon and Cytokine Research, vol. 19, no. 10, pp. 1153-1160, 1999.

[56] Y. Weisblum, A. Panet, Z.-R. Zichria et al., "Modeling of human cytomegalovirus maternal-fetal transmission in a novel decidual organ culture," Journal of Virology, vol. 85, no. 24, pp. 13204-13213, 2011.

[57] H. Kumar, T. Kawai, and S. Akira, "Toll-like receptors and innate immunity," Biochemical and Biophysical Research Communications, vol. 388, no. 4, pp. 621-625, 2009.

[58] H. Kumar, T. Kawai, and S. Akira, "Pathogen recognition by the innate immune system," International Reviews of Immunology, vol. 30, no. 1, pp. 16-34, 2011.

[59] S. Kijpittayarit, A. J. Eid, R. A. Brown, C. V. Paya, and R. R. Razonable, "Relationship between Toll-like receptor 2 polymorphism and cytomegalovirus disease after liver transplantation," Clinical Infectious Diseases, vol. 44, no. 10, pp. 1315-1320, 2007.

[60] S. H. Kang, R. C. Abdel-Massih, R. A. Brown, R. A. Dierkhising, W. K. Kremers, and R. R. Razonable, "Homozygosity for the tolllike receptor $2 \mathrm{R} 753 \mathrm{Q}$ single-nucleotide polymorphism is a risk factor for cytomegalovirus disease after liver transplantation," The Journal of Infectious Diseases, vol. 205, no. 4, pp. 639-646, 2012.

[61] S. Chaudhuri, B. Lowen, G. Chan, A. Davey, M. Riddell, and L. J. Guilbert, "Human cytomegalovirus interacts with tolllike receptor 2 and CD14 on syncytiotrophoblasts to stimulate expression of TNFalpha mRNA and apoptosis," Placenta, vol. 30, no. 11, pp. 994-1001, 2009.

[62] G. Chan and L. J. Guilbert, "Ultraviolet-inactivated human cytomegalovirus induces placental syncytiotrophoblast apoptosis in a Toll-like receptor- 2 and tumour necrosis factor- $\alpha$ dependent manner," Journal of Pathology, vol. 210, no. 1, pp. 111$120,2006$.

[63] K. W. Boehme, M. Guerrero, and T. Compton, "Human cytomegalovirus envelope glycoproteins $\mathrm{B}$ and $\mathrm{H}$ are necessary for TLR2 activation in permissive cells," Journal of Immunology, vol. 177, no. 10, pp. 7094-7102, 2006.

[64] L. K. Juckem, K. W. Boehme, A. L. Feire, and T. Compton, "Differential initiation of innate immune responses induced by human cytomegalovirus entry into fibroblast cells," Journal of Immunology, vol. 180, no. 7, pp. 4965-4977, 2008.

[65] A. Casrouge, S.-Y. Zhang, C. Eidenschenk et al., "Herpes simplex virus encephalitis in human UNC-93B deficiency," Science, vol. 314, no. 5797, pp. 308-312, 2006.
[66] S.-Y. Zhang, E. Jouanguy, S. Ugolini et al., "TLR3 deficiency in patients with herpes simplex encephalitis," Science, vol. 317, no. 5844, pp. 1522-1527, 2007.

[67] A. Nahum, H. Dadi, A. Bates, and C. M. Roifman, "The biological significance of TLR3 variant, L412F, in conferring susceptibility to cutaneous candidiasis, CMV and autoimmunity," Autoimmunity Reviews, vol. 11, no. 5, pp. 341-347, 2012.

[68] M. Mezger, M. Bonin, T. Kessler, F. Gebhardt, H. Einsele, and J. Loeffler, "Toll-like receptor 3 has no critical role during early immune response of human monocyte-derived dendritic cells after infection with the human cytomegalovirus strain TB40E," Viral Immunology, vol. 22, no. 6, pp. 343-351, 2009.

[69] R. Arav-Boger, G. L. Wojcik, P. Duggal et al., "Polymorphisms in Toll-like receptor genes influence antibody responses to cytomegalovirus glycoprotein B vaccine," BMC Research Notes, vol. 5, article 140, 2012.

[70] I. Roth, D. B. Corry, R. M. Locksley, J. S. Abrams, M. J. Litton, and S. J. Fisher, "Human placental cytotrophoblasts produce the immunosuppressive cytokine interleukin 10," The Journal of Experimental Medicine, vol. 184, no. 2, pp. 539-548, 1996.

[71] G. M. Scott, S. S. W. Chow, M. E. Craig et al., "Cytomegalovirus infection during pregnancy with maternofetal transmission induces a proinflammatory cytokine bias in placenta and amniotic fluid," The Journal of Infectious Diseases, vol. 205, no. 8, pp. 1305-1310, 2012.

[72] R. Arsenescu, V. Arsenescu, and W. J. S. de Villiers, "TNF- $\alpha$ and the development of the neonatal immune system: implications for inhibitor use in pregnancy," The American Journal of Gastroenterology, vol. 106, no. 4, pp. 559-562, 2011.

[73] J. P. Gisbert and M. Chaparro, "Safety of anti-TNF agents during pregnancy and breastfeeding in women with inflammatory bowel disease," The American Journal of Gastroenterology, 2013.

[74] P. A. Velilla, M. T. Rugeles, and C. A. Chougnet, "Defective antigen-presenting cell function in human neonates," Clinical Immunology, vol. 121, no. 3, pp. 251-259, 2006.

[75] L. Drohan, J. J. Harding, B. Holm et al., "Selective developmental defects of cord blood antigen-presenting cell subsets," Human Immunology, vol. 65, no. 11, pp. 1356-1369, 2004.

[76] J. Renneson, B. Dutta, S. Goriely et al., "IL-12 and type I IFN response of neonatal myeloid DC to human CMV infection," European Journal of Immunology, vol. 39, no. 10, pp. 2789-2799, 2009.

[77] J. Hassan, S. Dooley, and W. Hall, "Immunological response to cytomegalovirus in congenitally infected neonates," Clinical and Experimental Immunology, vol. 147, no. 3, pp. 465-471, 2007.

[78] S. T. Hamilton, G. Scott, Z. Naing et al., "Human cytomegalovirus-induces cytokine changes in the placenta with implications for adverse pregnancy outcomes," PloS One, vol. 7, no. 12, Article ID e52899, 2012.

[79] P. Griffiths, S. Plotkin, E. Mocarski et al., "Desirability and feasibility of a vaccine against cytomegalovirus," Vaccine, vol. 31, supplement 2, pp. B197-B203, 2013.

[80] S. Visentin, R. Manara, L. Milanese et al., "Early primary cytomegalovirus infection in pregnancy: maternal hyperimmunoglobulin therapy improves outcomes among infants at 1 year of age," Clinical Infectious Diseases, vol. 55, no. 4, pp. 497503, 2012.

[81] E. Polilli, G. Parruti, F. D’Arcangelo et al., "Preliminary evaluation of the safety and efficacy of standard intravenous immunoglobulins in pregnant women with primary cytomegalovirus infection," Clinical and Vaccine Immunology, vol. 19, no. 12, pp. 1991-1993, 2012. 
[82] M. Rola Pleszczynski, L. D. Frenkel, D. A. Fuccillo et al., "Specific impairment of cell mediated immunity in mothers of infants with congenital infection due to cytomegalovirus," The Journal of Infectious Diseases, vol. 135, no. 3, pp. 386-391, 1977.

[83] S. E. Starr, M. D. Tolpin, H. M. Friedman, K. Paucker, and S. A. Plotkin, "Impaired cellular immunity to cytomegalovirus in congenitally infected children and their mothers," The Journal of Infectious Diseases, vol. 140, no. 4, pp. 500-505, 1979.

[84] T. Fujikawa, K. Numazaki, H. Asanuma, R. Kudo, and H. Tsutsumi, "Frequency of human cytomegalovirus-specific T cells during pregnancy determined by intracellular cytokine staining," Journal of Medical Virology, vol. 71, no. 4, pp. 527-531, 2003.

[85] D. Lilleri, C. Fornara, M. Furione, M. Zavattoni, M. G. Revello, and G. Gerna, "Development of human cytomegalovirusspecific $\mathrm{T}$ cell immunity during primary infection of pregnant women and its correlation with virus transmission to the fetus," The Journal of Infectious Diseases, vol. 195, no. 7, pp. 1062-1070, 2007.

[86] M. G. Revello, D. Lilleri, M. Zavattoni et al., "Lymphoproliferative response in primary human cytomegalovirus (HCMV) infection is delayed in HCMV transmitter mothers," The Journal of Infectious Diseases, vol. 193, no. 2, pp. 269-276, 2006.

[87] H. Stern, G. Hannington, J. Booth, and D. Moncrieff, "An early marker of fetal infection after primary cytomegalovirus infection in pregnancy," British Medical Journal, vol. 292, no. 6522, pp. 718-720, 1986.

[88] S. Fernando, J. M. Pearce, and J. C. Booth, "Lymphocyte responses and virus excretion as risk factors for intrauterine infection with cytomegalovirus," Journal of Medical Virology, vol. 41, no. 2, pp. 108-113, 1993.

[89] C. Fornara, D. Lilleri, M. G. Revello et al., "Kinetics of effector functions and phenotype of virus-specific and $\gamma \delta$ T lymphocytes in primary human cytomegalovirus infection during pregnancy," Journal of Clinical Immunology, vol. 31, no. 6, pp. 1054-1064, 2011.

[90] D. Lilleri, C. Fornara, M. G. Revello, and G. Gerna, "Human cytomegalovirus-specific memory CD8+ and CD4+ T cell differentiation after primary infection," The Journal of Infectious Diseases, vol. 198, no. 4, pp. 536-543, 2008.

[91] W. Tu, S. Chen, M. Sharp et al., "Persistent and selective deficiency of CD4+ $\mathrm{T}$ cell immunity to cytomegalovirus in immunocompetent young children," Journal of Immunology, vol. 172, no. 5, pp. 3260-3267, 2004.

[92] T. Fujikawa, K. Numazaki, H. Asanuma, and H. Tsutsumi, "Human cytomegalovirus infection during pregnancy and detection of specific T cells by intracellular cytokine staining," International Journal of Infectious Diseases, vol. 7, no. 3, pp. 215221, 2003.

[93] N. Hayashi, H. Kimura, T. Morishima, N. Tanaka, T. Tsurumi, and K. Kuzushima, "Flow cytometric analysis of cytomegalovirus-specific cell-mediated immunity in the congenital infection," Journal of Medical Virology, vol. 71, no. 2, pp. 251-258, 2003.

[94] A. K. Lidehall, M. L. Engman, F. Sund et al., "Cytomegalovirusspecific CD4 and CD8 T cell responses in infants and children," Scandinavian Journal of Immunology, vol. 77, no. 2, pp. 135-143, 2013.

[95] O. Fornara, J. Odeberg, Z. Khan et al., "Human cytomegalovirus particles directly suppress CD4 T-lymphocyte activation and proliferation," Immunobiology, vol. 218, no. 8, pp. 1034-1040, 2013.
[96] A. Teles, A. C. Zenclussen, and A. Schumacher, "Regulatory T cells are baby's best friends," American Journal of Reproductive Immunology, vol. 69, no. 4, pp. 331-339, 2013.

[97] J. H. Rowe, J. M. Ertelt, L. Xin, and S. S. Way, "Pregnancy imprints regulatory memory that sustains anergy to fetal antigen," Nature, vol. 490, no. 7418, pp. 102-106, 2012.

[98] B. T. Rouse, P. P. Sarangi, and S. Suvas, "Regulatory T cells in virus infections," Immunological Reviews, vol. 212, pp. 272-286, 2006.

[99] Y. Belkaid, "Regulatory $\mathrm{T}$ cells and infection: a dangerous necessity," Nature Reviews Immunology, vol. 7, no. 11, pp. 875888, 2007.

[100] A. Egli, M. Silva Jr., D. O’Shea et al., "An analysis of regulatory Tcell and Th-17 cell dynamics during cytomegalovirus replication in solid organ transplant recipients," PloS One, vol. 7, no. 11, Article ID e43937, 2012.

[101] E. M. Aandahl, J. Michaëlsson, W. J. Moretto, F. M. Hecht, and D. F. Nixon, "Human CD4+ CD25+ regulatory T cells control T-cell responses to human immunodeficiency virus and cytomegalovirus antigens," Journal of Virology, vol. 78, no. 5, pp. 2454-2459, 2004.

[102] S. Velaga, S. N. Ukena, M. Hopting et al., "Reconstitution and phenotype of Tregs in CMV reactivating patients following allogeneic hematopoietic stem cell transplantation," Immunological Investigations, vol. 42, no. 1, pp. 18-35, 2013.

[103] C. La Rosa and D. J. Diamond, "The immune response to human CMV," Future Virology, vol. 7, no. 3, pp. 279-293, 2012.

[104] M. R. Wills, A. J. Carmichael, K. Mynard et al., "The human cytotoxic T-lymphocyte (CTL) response to cytomegalovirus is dominated by structural protein pp65: frequency, specificity, and T-cell receptor usage of pp65-specific CTL," Journal of Virology, vol. 70, no. 11, pp. 7569-7579, 1996.

[105] R. Elkington, S. Walker, T. Crough et al., "Ex vivo profiling of CD8+-T-cell responses to human cytomegalovirus reveals broad and multispecific reactivities in healthy virus carriers," Journal of Virology, vol. 77, no. 9, pp. 5226-5240, 2003.

[106] A. W. Sylwester, B. L. Mitchell, J. B. Edgar et al., "Broadly targeted human cytomegalovirus-specific CD4+ and CD8+ T cells dominate the memory compartments of exposed subjects," The Journal of Experimental Medicine, vol. 202, no. 5, pp. 673685, 2005.

[107] J. Hassan and J. Connell, “Translational mini-review series on infectious disease: congenital cytomegalovirus infection: 50 years on," Clinical and Experimental Immunology, vol. 149, no. 2, pp. 205-210, 2007.

[108] L. Gibson, S. Donley, S. Trzmielina et al., "Cytomegalovirus (CMV) IE1- and pp65-specific CD8+ T cell responses broaden over time after primary CMV infection in infants," The Journal of Infectious Diseases, vol. 195, no. 12, pp. 1789-1798, 2007.

[109] B. Pédron, V. Guérin, F. Jacquemard et al., "Comparison of CD8+ $\mathrm{T}$ cell responses to cytomegalovirus between human fetuses and their transmitter mothers," The Journal of Infectious Diseases, vol. 196, no. 7, pp. 1033-1043, 2007.

[110] M. A. E. Ould, D. Luton, M. Yadini et al., "Cellular immune response of fetuses to cytomegalovirus," Pediatric Research, vol. 55, no. 2, pp. 280-286, 2004.

[111] A. Marchant, V. Appay, M. Van Der Sande et al., "Mature CD8+ T lymphocyte response to viral infection during fetal life," The Journal of Clinical Investigation, vol. 111, no. 11, pp. 1747-1755, 2003. 
[112] A. Marchant and M. Goldman, "T cell-mediated immune responses in human newborns: ready to learn?" Clinical and Experimental Immunology, vol. 141, no. 1, pp. 10-18, 2005.

[113] P. G. Holt, "Functionally mature virus-specific CD8+ T memory cells in congenitally infected newborns: proof of principle for neonatal vaccination?" The Journal of Clinical Investigation, vol. 111, no. 11, pp. 1645-1647, 2003.

[114] W. K. Born, N. Jin, M. K. Aydintug et al., " $\gamma \delta$ T lymphocytesselectable cells within the innate system?" Journal of Clinical Immunology, vol. 27, no. 2, pp. 133-144, 2007.

[115] D. Vermijlen, M. Brouwer, C. Donner et al., "Human cytomegalovirus elicits fetal $\gamma \delta \mathrm{T}$ cell responses in utero," The Journal of Experimental Medicine, vol. 207, no. 4, pp. 807-821, 2010.

[116] R. F. Pass, C. H. Zhang, A. Evans et al., "Vaccine prevention of maternal cytomegalovirus infection," The New England Journal of Medicine, vol. 360, no. 12, pp. 1191-1199, 2009.

[117] P. D. Griffiths, A. Stanton, E. McCarrell et al., "Cytomegalovirus glycoprotein-B vaccine with MF59 adjuvant in transplant recipients: a phase 2 randomised placebo-controlled trial," The Lancet, vol. 377, no. 9773, pp. 1256-1263, 2011.

[118] S. Sabbaj, R. F. Pass, P. A. Goepfert, and S. Pichon, "Glycoprotein $\mathrm{B}$ vaccine is capable of boosting both antibody and CD4 T-cell responses to cytomegalovirus in chronically infected women," The Journal of Infectious Diseases, vol. 203, no. 11, pp. 1534-1541, 2011.

[119] M. R. Schleiss, "Could therapeutic vaccination of cytomegalovirus-seropositive persons prevent reinfection and congenital virus transmission?" The Journal of Infectious Diseases, vol. 203, no. 11, pp. 1513-1516, 2011.

[120] E. F. Chakravarty, E. R. Murray, A. Kelman, and P. Farmer, "Pregnancy outcomes after maternal exposure to rituximab," Blood, vol. 117, no. 5, pp. 1499-1506, 2011.

[121] L. Le Clech, J. C. Ianotto, I. Quintin-Roue, and A. Tempescul, "Severe CMV complication following maintenance therapy with rituximab," BMJ Case Reports, 2013.

[122] K. Ahlfors, S.-A. Ivarsson, and S. Harris, "Report on a long-term study of maternal and congenital cytomegalovirus infection in Sweden. Review of prospective studies available in the literature," Scandinavian Journal of Infectious Diseases, vol. 31, no. 5, pp. 443-457, 1999.

[123] S. A. Ross, N. Arora, Z. Novak, K. B. Fowler, W. J. Britt, and S. B. Boppana, "Cytomegalovirus reinfections in healthy seroimmune women," The Journal of Infectious Diseases, vol. 201, no. 3, pp. 386-389, 2010.

[124] G. Nigro, S. P. Adler, R. La Torre, A. M. Best, and Congenital Cytomegalovirus Collaborating Group, "Passive immunization during pregnancy for congenital cytomegalovirus infection," The New England Journal of Medicine, vol. 353, no. 13, pp. 13501362, 2005.

[125] F. P. McCarthy, M. L. Giles, S. Rowlands, K. J. Purcell, and C. A. Jones, "Antenatal interventions for preventing the transmission of cytomegalovirus (CMV) from the mother to fetus during pregnancy and adverse outcomes in the congenitally infected infant," Cochrane Database of Systematic Reviews, vol. 3, Article ID CD008371, 2011.

[126] G. Nigro, R. La Torre, H. Pentimalli et al., "Regression of fetal cerebral abnormalities by primary cytomegalovirus infection following hyperimmunoglobulin therapy," Prenatal Diagnosis, vol. 28, no. 6, pp. 512-517, 2008.

[127] G. Nigro, S. P. Adler, G. Parruti et al., "Immunoglobulin therapy of fetal cytomegalovirus infection occurring in the first half of pregnancy-a case-control study of the outcome in children," The Journal of Infectious Diseases, vol. 205, no. 2, pp. 215-227, 2012.

[128] A. E. Fouts, P. Chan, J. P. Stephan, R. Vandlen, and B. Feierbach, "Antibodies against the gH/gL/UL128/UL130/UL131 complex comprise the majority of the anti-cytomegalovirus (anti-CMV) neutralizing antibody response in CMV hyperimmune globulin," Journal of Virology, vol. 86, no. 13, pp. 7444-7447, 2012.

[129] H. Buxmann, O. M. Stackelberg, R. L. Schlosser et al., "Use of cytomegalovirus hyperimmunoglobulin for prevention of congenital cytomegalovirus disease: a retrospective analysis," Journal of Perinatal Medicine, vol. 40, no. 4, pp. 439-446, 2012.

[130] R. La Torre, G. Nigro, M. Mazzocco, A. M. Best, and S. P. Adler, "Placental enlargement in women with primary maternal cytomegalovirus infection is associated with fetal and neonatal disease," Clinical Infectious Diseases, vol. 43, no. 8, pp. 994-1000, 2006.

[131] E. Maidji, G. Nigro, T. Tabata et al., "Antibody treatment promotes compensation for human cytomegalovirus-induced pathogenesis and a hypoxia-like condition in placentas with congenital infection," American Journal of Pathology, vol. 177, no. 3, pp. 1298-1310, 2010.

[132] E. Maidji, S. McDonagh, O. Genbacev, T. Tabata, and L. Pereira, "Maternal antibodies enhance or prevent cytomegalovirus infection in the placenta by neonatal Fc receptor-mediated transcytosis," American Journal of Pathology, vol. 168, no. 4, pp. 1210-1226, 2006

[133] E. C. Neto, R. Rubin, J. Schulte, and R. Giugliani, "Newborn screening for congenital infectious diseases," Emerging Infectious Diseases, vol. 10, no. 6, pp. 1069-1073, 2004. 


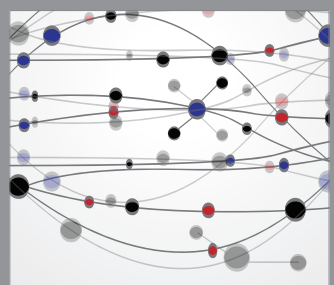

The Scientific World Journal
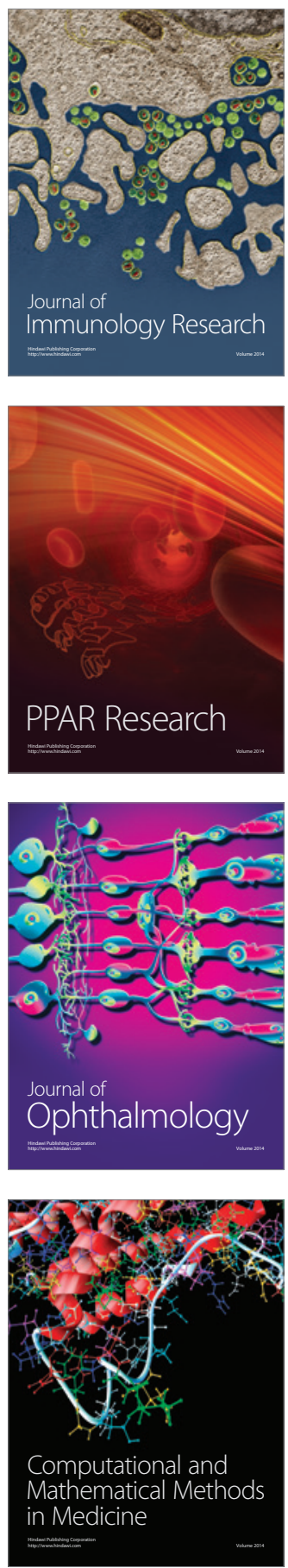

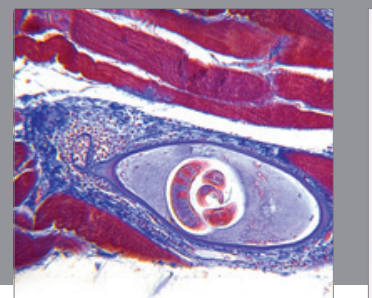

Gastroenterology

Research and Practice
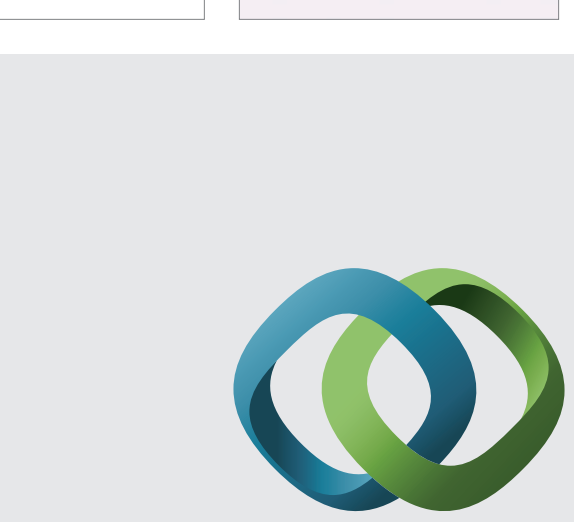

\section{Hindawi}

Submit your manuscripts at

http://www.hindawi.com
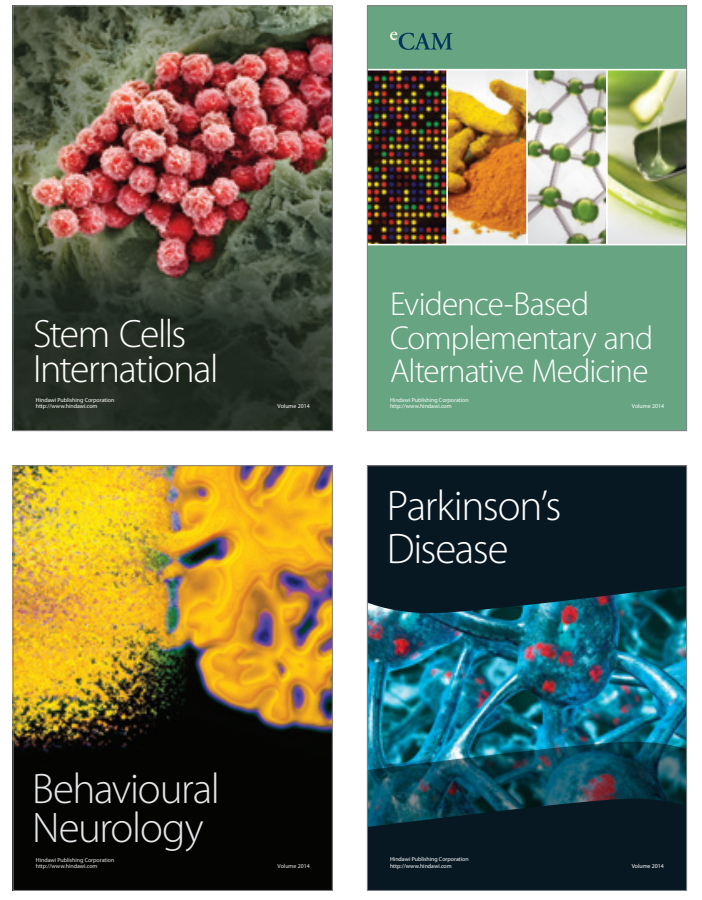
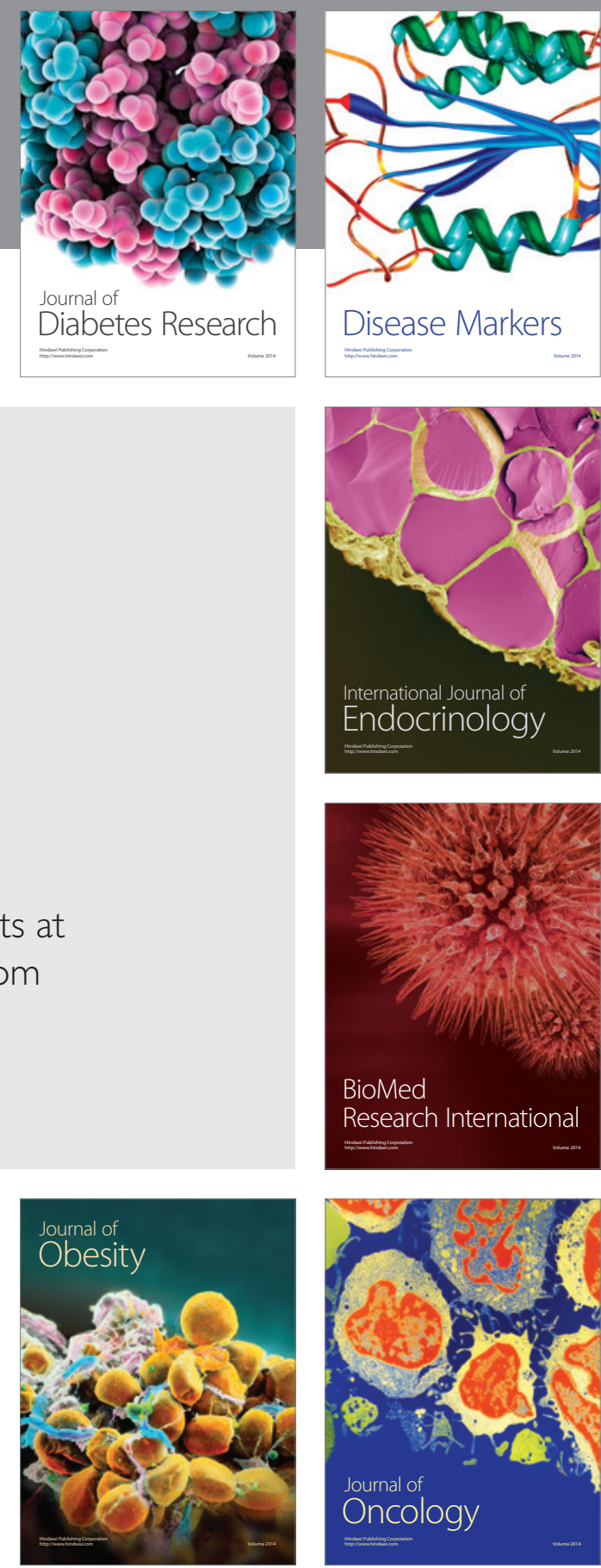

Disease Markers
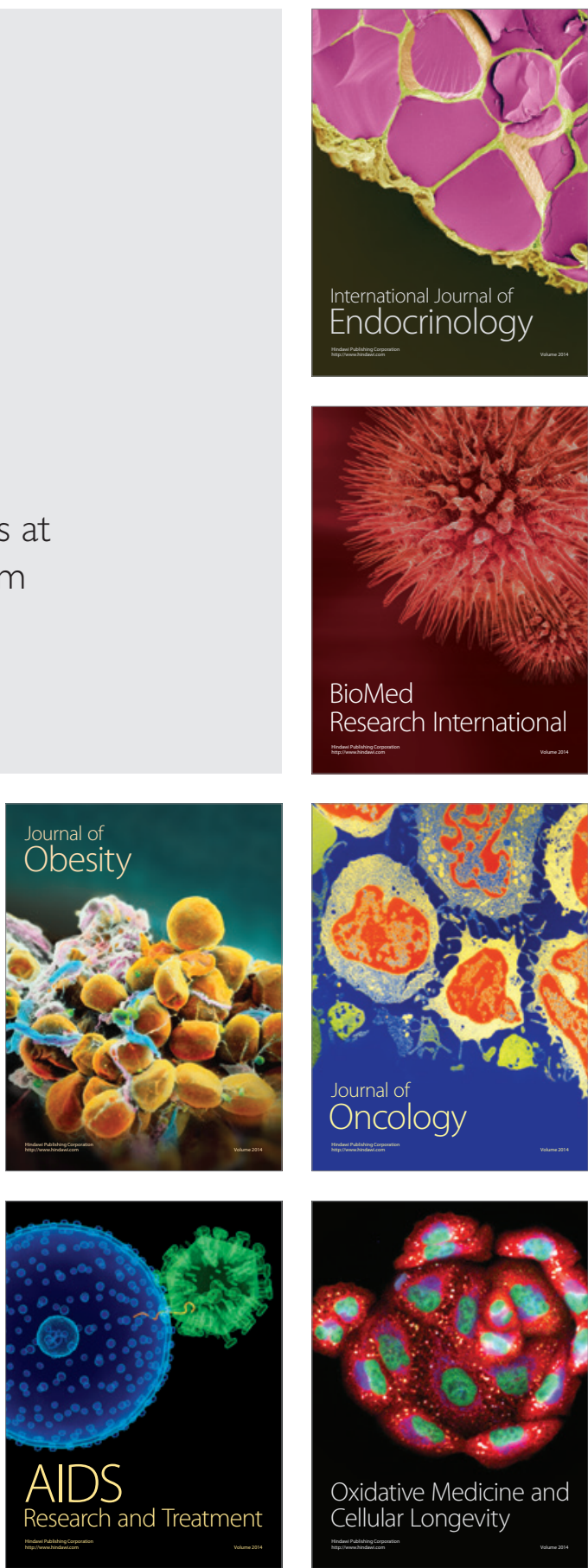